\title{
KESADARAN HUKUM SEBAGAI ASPEK DASAR POLITIK HUKUM LEGISLASI: SUATU TINJAUAN FILSAFAT
}

(Legal Awareness as Basis of Legal Policy on Legislation: a Philosophical Overview)

\author{
Wenda Hartanto \\ Kantor Wilayah Kementerian Hukum dan HAM Riau \\ Jl.Jend.Sudirman No.233 Pekanbaru \\ Email : wendahartanto@yahoo.com
}

Naskah diterima: 14 Oktober 2015; revisi: 27 November 2015; disetujui: 2 Desember 2015

\begin{abstract}
Abstrak
Manusia seperti entitas lainnya, juga bereksistensi. Namun, eksistensi manusia berbeda karena memiliki kesadaran. Sedangkan hukum memiliki tujuan yang mulia yaitu untuk membentuk masyarakat berada dalam tatanan hukum dan berperan sebagai sarana rekayasa sosial demi kemajuan. Namun kesadaran hukum sebagai suatu entitas yang tunggal dibenturkan pada masyarakat plural dengan pandangan-pandangan yang majemuk. Suatu kumpulan individu yang majemuk juga memunculkan kaidah hukum jika disepakati dapat dianggap memiliki aspek moralitas dan kesadaran hukum oleh suatu golongan, tetapi tidak demikian oleh golongan yang lain. Dalam keadaan yang semacam itu, menjadi sangat penting untuk mengetahui bagaimana terjadinya proses relasi antara kesadaran hukum dan politik hukum dalam proses legislasi, serta bagaimana konsep ideal untuk mengakomodir kesadaran hukum masyarakat dalam proses legislasi. Dengan menggunakan metode penelitian hukum normatif bisa dilihat bahwa proses legislasi merupakan aktualisasi politik hukum yang berdasarkan kesadaran hukum masyarakat untuk mencapai tujuan dan melindungi kebutuhan dan kepentingan masyarakat. Indonesia sebagai negara bangsa yang majemuk memerlukan suatu sistem hukum modern yang mampu mengantisipasi serta mengatasi berbagai permasalahan yang mungkin akan timbul. Nilai-nilai Pancasila hadir untuk mengakomodir dimensi kepentingan politik, ekonomi, sosial dan politik manusia sebagai subjek didalam bernegara.
\end{abstract}

Kata Kunci: kesadaran hukum, politik legislasi, Pancasila

\section{Abstract}

Humans like other entities, also exist. However, human existence is different because it has consciousness. While the law has a noble purpose which is to establish a community within the legal system and to serve as tools of social engineering for progression. However, legal awareness as a single entity collides with a plural society with diverse views. A group of diverse individuals make some law, which is agreed by some group, can be considered to have morality aspects and legal awareness by that groups, but not by the other groups. In such circumstances, it becomes very important to understand the process of the relationship between legal awareness and legal policy in the legislation process, and what the ideal concept to accommodate the public legal awareness in the legislation process. By using the normative legal research method, it can be seen that the legislation process is an actualization of legal policy which is based on public legal awareness which aims to protect public needs and interests. Indonesia as a plural nation state require a modern legal system which is able to anticipate and overcome every problems that may arise. Pancasila Values exists here to accommodate the dimensions of political, economic, and social interests of human being as the subject of state.

Keywords: legal awareness, legislation policy, Pancasila 


\section{A. Pendahuluan}

Pengetahuan manusia bersifat paradoks. Dikatakan demikian karena kedua jenis pengetahuan yaitu prapengetahuan (yang implisit dan kabur, namun tak terbatas dan ekshautif) dan pengetahuan (yang bersifat eksplisitasi terang, namun terbatas) tidak pernah terpisahkan yang implisit dan eksplisit, yang mutlak dan relatif serta ilahi dan manusiawi tak pernah terlepas satu dengan yang lainnya. Pertanyaan tentang apakah manusia merupakan pertanyaan yang tiada henti-hentinya digarap oleh para filsuf, salah satunya Jean-Paul Sartre. Sartre melihat manusia berada dalam konflik eksistensial antara Ada dan Tiada. Sartre adalah seorang filsuf eksistensialis Perancis. Eksistensialisme merupakan filsafat yang bergulat dalam perkara eksistensialis, khususnya eksistensi manusia. Sartre menyatakan bahwa eksistensi tersebut mendahului esensi. Menurut Sartre, manusia lebih tinggi derajatnya dari pada entitas lainnya, karena manusia tidak memiliki kodrat yang sudah ditentukan sebelumnya. Manusia seperti entitas lainnya, juga bereksistensi. Namun, eksistensi manusia berbeda karena memiliki kesadaran ${ }^{1}$.

Hukum memiliki tujuan yang mulia yaitu untuk membentuk masyarakat beradadalam tatanan hukum. Pengandaian paling pokok terkait pentingnya kesadaran hukum untuk manusia adalah bahwa manusia adalah makhluk yang tak cukup diri. Hal ini berbeda dengan binatang. Situasi ketidak-cukupan ini mendorong manusia menciptakan struktur eksternal supaya bisa hidup dengan lebih baik.
Hukum dan segala aturan adalah struktur virtual atau struktur yang tak kelihatan sebagai penyokong hidup manusia tadi. Melihat sifat dasar individu manusia tadi, masyarakat yang mendasarkan pada hukum yang minimal itu biasanya bersifat statis. Pada umumnya manusia itu bersifat malas dan enggan sakit, kemajuan sosial tidak bisa terjadi secara spontan. Hukum lalu bisa berperan sebagai rekayasa sosial demi kemajuan itu. Dalam hal ini kesadaran hukum menjadi pengikat atau bahasa bersama sebagai trust system maupun sebagai cita-cita.

Hukum pada awalnya berfungsi untuk mengatur tingkah laku manusia dan mempertahankan pola-pola kebiasaan yang sudah ada dalam masyarakat, tetapi dalam perkembangannya hukum berfungsi sebagai sarana untuk mencapai tujuan. Hukum dimanapun akan tumbuh dari cara hidup, pandangan hidup dan kebutuhan hidup masyarakatnya, sehingga hukum akan tumbuh dan berkembang bersama masyarakatnya, $\mathrm{Hal}$ ini sebagaimana diajarkan Rescoe Pound, bahwa hukum itu adalah lembaga kemasyarakatan untuk memenuhi kebutuhan sosial². Garis penyeimbang akan semakin tersajikan didalam kehidupan jika manusia tersebut dapat merelasikan nilai didalam pola pikirnya yang diejawantahkan kedalam pola tindaknya, jadi titik tekan untuk kesadaran hukum ini adalah kesinergisan antara pola pikir dan pola tindak manusia.

Melalui filosofi rasionalisme dan empirisme, masyarakat dipahami sebagai kesatuan dari individu-individu terpisah yang membangun ikatan pribadi sebelum munculnya masyarakat

Donny Gahral Adian, Percik Pemikiran Kontemporer (Yogyakarta: Jalasutra, 2006), hlm. 162.

Sebagaimana dikutip Sunarjati Hartono, Capita Selecta Perbandingan Hukum (Bandung: Alumni, 1968), hlm. 58. 
itu sendiri. Pencarian akan analisis rasional mengenai masyarakat dimulai dengan fenomena tunggal yang bisa diamati yang dijumpai dalam sejarah dan kehidupan sosial. Dengan kata lain pandangan mekanistik dan atomistic mempengaruhi cara memahami hubungan politik dan sosial ${ }^{3}$. Berdasarkan hubungan ini, kesadaran sebagai suatu nilai diandaikan eksis dan seharusnya tercermin dalam hukum. Tetapi menjadi persoalan, kesadaran hukum sebagai suatu entitas yang tunggal dibenturkan pada masyarakat plural dengan pandanganpandangan yang majemuk. Suatu kumpulan individu yang majemuk juga memunculkan kaidah hukum jika disepakati dapat dianggap memiliki aspek moralitas dan kesadaran hukum oleh suatu golongan, tetapi tidak demikian oleh golongan yang lain. Apakah dengan demikian kesadaran hukum sejatinya bukanlah entitas yang tunggal, tetapi justru suatu ide yang relatif? Jika demikian tentunya merupakan suatu kesia-siaan untuk mendiskusikan antara kesadaran hukum dalam pembentukan norma hukum. Oleh karena itu dibutuhkan teori yang menawarkan metode untuk memecahkan kebuntuan tersebut dengan adanya pencapaian kesepahaman terhadap nilai-nilai yang universal.

Manusia dalam kehidupan sehari-hari hampir di segala bidang diatur oleh hukum kemudian hukum dikristalisasi dalam bentuk peraturan perundang-undangan yang pada dasarnya lebih merupakan tata aturan hubungan hukum antara individu dengan negara atau antar individu dan apabila ditelisik lebih dalam, gagasan pembentukan peraturan perundangundang bermula ketika ada konflik atau muncul ketidaktertibanantaranggota dalam masyarakat. Hal ini mengingatkan pada eksponen mazhab sejarah Von Savigny juga mengatakan hukum tidak dibuat oleh negara, melainkan ditemukan di dalam masyarakat itu sendiri. Konsekuensi logis yang harus diterima sebagai negara hukum adalah setiap kebijakan publik (public policy) selalu berkait dengan perundang-undangan. Hukum sebagai perangkat kaidah sosial yang salah satu tugasnya menciptakan pergaulan hidup damai, dalam penegakannya kerap kali juga mesti memperhatikan pertimbanganpertimbangan etis yang dapat dijadikan sebagai patokan agar tidak terjadi konflik ketika terjadi benturan-benturan penerapan beberapa perangkat hukum (aturan).

Persoalan pembentukan hukum dan penerapan hukum di masyarakat ditentukan oleh hubungan yang saling terikat antara kesadaran hukum dan politik hukum. Kesadaran hukum sebenarnya merupakan kesadaran akan nilai-nilai yang terdapat di dalam diri manusia, tentang hukum yang ada atau tentang hukum yang diharapkan ada. yang ditekankan adalah nilai-nilai tentang fungsi hukum dan suatu penilaian (menurut) hukum terhadap kejadiankejadian yang konkrit dalam masyarakat yang bersangkutan. Kalau dilihat sejarahnya bahwa hukum ada karena manusia, rumusan fungsional akan tampak lebih originalitas setidaknya secara kronologis, dibanding rumusan secara esensial. Selain itu, ada kaitan yang saling mengandaikan antara hukum dan masyarakat. Hukum adalah keniscayaan (conditio sine qua non) bagi masyarakat. Apalagi di zaman modern ini, tidak ada masyarakat tanpa hukum. Sebaliknya pula, hukum tidak ada tanpa masyarakat,

George Ritzer dan Barry Smart, Hand Book Teori Sosial, (Jakarta: Nusamedia,2012), hlm. 25. 
karena hukum bersifat relasional. Seorang manusia yang hidup sendirian di suatu pulau tidak perlu hukum. Kaitan erat antara hukum dengan masyarakat ini bisa menjadi garis bawah dari pentingnya dimensi fungsional atau instrumental hukum. Dengan kata lain, hukum tidak mempunyai tujuan pada dirinya sendiri. Tujuan hukum diisi oleh masyarakat pembuatnya berdasarkan konfigurasi politik yang terjadi ditengah kondisi dan keadaan yang dipengaruhi oleh berbagai faktor. Tentu saja, isi tujuan itu juga tergantung pada pemahaman diri dan kesadaran hukum masyarakat itu sendiri untuk merealisasikannya menjadi sebuah kebijakan hukum yang berdasarkan kesadaran hukum komunal. Krabbe mengatakan bahwa sumber segala hukum adalah kesadaran hukum ${ }^{4}$.

Politik hukum merupakan legal policy atau garis (kebijakan) resmi tentang hukum yang akan diberlakukan baik dengan pembuatan hukum atau norma baru maupun dengan penggantian hukum lama, dalam rangka mencapai tujuan negara. Dengan demikian, politik hukum merupakan pilihan tentang hukum-hukum yang akan diberlakukan sekaligus pilihan tentang hukum-hukum yang akan dicabut atau tidak diberlakukan yang kesemuanya dimaksudkan untuk mencapai tujuan negara seperti yang tercantum di dalam Pembukaan UUD $1945^{5}$. Merupakan suatu keharusan bagi suatu negara tatkalamerumuskansuatuperaturan perundangundangannya senantiasa memperhatikan pada aspek tujuan negara (national interests). Selain kesadaran hukum masyarakat sebagai landasan ideal dalam proses pembentukan peraturan perundang-undanganuntuk dapat mencapai tujuan Negara tersebut, maka faktor politik hukum juga akan sangat menentukan. Peranan politik hukum dalam konteks sosio-antropoligis memegang peranan yang strategis. Melalui kacamata politik hukum, hukum yang dibentuk pun setidaknya akan menghasilkan faktorfaktor dan implikasi yang bersifat dualisme atau bernilai positif dan negatif dalam pembentukan, penerapan, dan keberlakuannya terhadap kepentingan masyarakat banyak sebagai respon dari kesadaran hukum masyarakat.

Dalam pergeseran analisis nantinya kelihatan adanya momentum gerak pergeseran dari yang semula menurut sudut pandang teoritisanalogis kepada penilaian praktis-aksiologis. Filsafat sebagai sebuah ilmu yang mengkaji hakekat, secara ontologis tidak lagi menjadi tujuan tersendiri atau berakhir di titik kajian seperti itu, tetapi supaya selanjutnya hasil kajian ontologis itu dapat juga dimanfaatkan secara epistemologis sebagai alat atau sarana untuk meneruskanlalumerekayasasuatustrategiuntuk hari depan. Itu berarti adanya perkembangan baru pada kebutuhan akan pengkajian nilainilai yang hidup dalam kehidupan masyarakat dengan cara pandang strategis dan futuristik, perkembangan nilai-nilai kesadaran hukum dan politik hukum harus dievaluasi. Ini berarti bahwa manusia dan kita sebagai bangsa bernegara dalam rangka pengelolaan kehidupan bangsa, harus mempersoalkan masih sah berlakunya nilai kesadaran hukum yang kini eksis, lalu mengadakan evaluasi dan mengangkat hasilnya menjadi policy atau kebijakan secara proaktif, untuk menyambut masa depan yang serba ketidakpastian.

Sebagaimana dikutip Singkeru Rukka, "Kearifan Lokal Dan Kesadaran Hukum", Jurnal Al-Risalah, Volume 13 Nomor 1 Mei (2013): 174.

5 Mahfud, M.D, Politik Hukum di Indonesia, (Jakarta: PT. Raja Grafindo Persada, 2012), hlm. 20. 
Peraturan perundang-undangan sebagai suatu cara pembuatan hukum secara sadar dengan sengaja dianggap sebagai suatu aktivitas yang tidak wajar, sehingga sesungguhnya tidak lebih hanya memberikan pengesahan dan legiltimasi saja terhadap norma-norma yang di bentuk secara informal oleh pergaulan hidup itu sendiri6. Oleh karena itu terbentuknya institusi perwakilan individu yang formal, seperti kecenderungan menyatunya pola kehidupan dalam satu kepentingan yang serupa sebagaimana penyatuan visi dan misi dariseluruh kesadaran hukum individu yang berbeda. Setiap kesadaran akan suatu nilai dan norma yang berkembang didalam masyarakat diharapkan dapat menjadi pedoman atau acuan bagaimana tingkahlaku seharusnya atau seharusnya dilakukan. Ketika nilai atau norma akan dipatuhi tanpa disadari atau seperti terpaut dengan kebiasaan atau suatu refleksi yang bersyarat dalam tiap-tiap kelompok terdapat susunan dan proses sosial yang berkorelasi sesuai dengan kaedah-kaedah norma itu. Individu atau kelompok akan didorong kearah persesuaian, akan tetapi dorongan tersebut dapat berubah menjadi paksaan sehingga kepatuhan akan sebuah kesepakatan tereduksi oleh pengaruh perubahan kepentingan, kebutuhan, dan kebiasaan di dalam proses sosial kehidupan masyarakat, akhirnya pengaruh itu berubah menjadi pelaksanaan kekuasaan yang mutlak dan kesadaran menjadi perbuatan yang tidak disadari hampir tanpa refleksi.
Dalam keadaan yang semacam itu, norma yang mengatur ragam pola aktivitas apakah kompatibel dan punya semangat yang sama antara kesadaran hukum dan politik hukum tersebut tentu jika ditelusuri asal-usul, hubungan sebab akibat, dalam kerangka pemikiran pembentukan dan implikasi sebuah norma menjadi fokus tulisan ini yaitu melihat bagaimana terjadinya proses relasi antara kesadaran hukum dan politik hukum dalam proses legislasi, bagaimana konsep ideal untuk mengakomodir kesadaran hukum masyarakat dalam proses legislasi tersebut serta peran filsafat hukum di dalam politik hukum dalam pembentukan hukum untuk memenuhi kebutuhan masyarakat.

\section{B. Metode penelitian}

Berdasarkan permasalahan dan latar belakang di atas maka metode yang digunakan adalah Penelitian hukum normatif ${ }^{7}$ yang dilakukan dengan cara meneliti bahan pustaka atau data sekunder Dalam model penelitian hukum ini terdapat konsep-konsep: konsistensi, deduktif, analisis, apriori, konkritisasi, interpretasi dan data kualitatif melalui library research. Target penelitian model ini adalah mendeskripsikan obyek sehingga disebut penelitian deskriptif.

\footnotetext{
6 Satjipto Rahardjo, Hukum Dan Masyarakat, (Bandung: Angkasa, 1980 ) hlm.112. Bandingkan dengan pandangan Soetandyo yang mengatakan bahwa old societies untuk masyarakat/komunitas lokal dan hukum lokal sebelum menuju nation state, dalam Soeandyo Wignyosoebroto, Hukum, paradigm, Dan Dinamika Masalahnya-Masalah Pluralisme Dalam Sistem Hukum Nasional, (Jakarta: Elsam, 2002), hlm. 301.

Penelitian yang dilakukan bersifat deskriptif yaitu menggambarkan gejala-gejala di lingkungan masyarakat terhadap suatu kasus yang diteliti, pendekatan yang dilakukan yaitu pendekatan kualitatif yang merupakan tata cara penelitian yang menghasilkan data deskriptif. Lebih jauh Soerjono Soekanto dan Sri Mamudji, Penelitian Hukum Normatif Suatu Tinjauan Singkat, Cetakan ke - 11. (Jakarta : PT Raja Grafindo Persada, 2009), hal. 13-14.
} 


\section{Pembahasan}

\section{Relasi Antara Kesadaran Hukum dan Politik Legislasi}

Martin Heidegger ${ }^{8}$ mengklasifikasikan eksistensialisme beberapa bagian, antara lain: Pertama, Eksistentialisme menekankan kesadaran "ada" (being)", dan eksistensi. Nilai kehidupan nampak melalui pengakuan terhadap individual, yakni "I (aku)" dan bukan "It". Kedua, Eksistentialisme percaya bahwa tak ada pengetahuan yang terpisah dari subyek yang mengetahui. Kita mengalami kebenaran dalam diri kita sendiri. Kebenaran tidak dapat dicapai secara abstrak. Ketiga, kebenaran itu subyektif, Ketiga, alam tidak menyediakan aturan moral. Prinsip-prinsip moral dikontruksi oleh manusia dalam konteks bertanggungjawab atas perbuatan mereka dan perbuatan selainnya; Keempat, perbuatan individu tidak dapat diprediksi; Kelima, individu mempunyai kebebasan kehendak secara sempurna; Keenam, individu tak dapat membantu melainkan sekedar membuat pilihan; dan Ketujuh, individu dapat secara sempurna menjadi selain dari pada keberadaannya.

Menimbang dari kriteria di atas maka manusia satu-satunya makhluk yang dibimbing oleh suatu pengetahuan yang samar tentang 'ada'. Manusia adalah ada yang unik, keunikan yang membedakannya dengan benda-benda dan membuatnya mampu mempersoalkan 'ada'. Karena manusia bukan benda maka Heidegger memilih istilah dasein untuk menunjukkan 'ada' manusia. Pemikiran Heidegger berporos pada suatu distingsi yang disebut pembedaan ontologi, yakni antara sein (ada) dan seinde (mengada) ${ }^{10}$. Fenomena pemikiran di atas menunjukkan kepada kita bahwa manusia, eksistensi manusia berbeda dengan yang bukan manusia di alam semesta dikarenakan adanya kesadaran yang ada pada manusia.

Menurut teori fusion of forizons dan hermeneutical circle dari Gadamer ${ }^{11}$, dalam menafsirkan sebuah teks, seseorang harus selalu berusaha memperbarui prapemahaman relevansinya dengan teori - penggabungan

Peter A. Angeles, A Dictionary of Philisophy, (London: Harper \& Row Publishers, 1981), hlm. 88.

$9 \quad$ F. Budi Hardiman, Heidegger dan Mistik Keseharian; Suatu Pengantar Menuju Sein und Zeit (Jakarta: KPG Kepustakan Populer Gramedia, 2003), hlm. 31-45.

10 Mengada atau seinde hanya berlaku pada benda-benda yang bukan manusia yang jikalau dipandang pada dirinya sendiri artinya: terpisah dari segala yang lain, hanya berdiri sendiri. Manusia sebenarnya juga berdiri sendiri, namun manusia dapat menanyakan ada karena memiliki hubungan dengan ada-nya. Tidak seperti mengada-mengada lain yang tidak sadar akan ada-nya. Hubungan dengan adanya itu yang disebut eksistensi. Eksistensi manusia atau dasein berbeda dengan benda-benda. Benda-benda tidak bisa mengambil jarak dengan keberadaannya, sedangkan manusia dapat mengambil jarak dan mempersoalkan. Menurut Heidegger, Dasein adalah benda-benda mengada dalam sang dunia (being-in-the-world) yang ditegaskan Heidegger di sini merupakan suatu -fenomena kesatuan\| (unitary phenomenon). Artinya,-ada\|l dasein dan dunia tidak terpisah dan berhadapan satu sama lain. Heidegger, Being and Time..., 78. Sedangkan dalam buku lain arti kata sein dan seinde diartikan dengan -berada\| untuk sein dan - yang ber berada \| untuk seinde. Lihat Harun Hadiwijono, Sari Sejarah Filsafat Barat 2 (Yogyakarta: Kanisius, 2002), hlm. 150.

11 Menurut Gadamer, human sciences selalu berusaha mendekati teks dari suatu posisi yang dijaga berjarak dari teks itu sendiri, yang disebut alienation, yang menghapuskan ikatan-ikatan yang sebelumnya telah dimiliki oleh interpreter dengan objek yang sedang diinterpretasikan. Menurut Gadamer, jarak tersebut dapat diatasi dan ikatan-ikatan tersebut dapat dibangun kembali (re-fusion) melalui mediasi kesadaran akan efek historis (consciousness of the effects of history). Lebih jauh lihat W. Poespoprodjo, Interpretasi-Beberapa Catatan Pendekatan Filosofisnya (Bandung: Remadja Karya, 1987), hlm. 93-118. 
atau asimilasi horison (fusion of horizons) ${ }^{12}$. Teori ini menganggap bahwa proses penafsiran seseorang dipengaruhi oleh dua horison, yakni horison makna teks dan horison makna pembaca. Kedua horison ini selalu hadir dalam setiap proses pemahaman dan penafsiran ${ }^{13}$. Teori ini memaknai kesadaran manusia sebagai satu kesatuan antara subjek dan objek yang saling berkaitan diantara jarak dan ikatan objek kesadaran manusia di dalam pemahaman tentang eksistensi kesadaran manusia. Perwujudan sikap yang memiliki kesadaran selaras dan saling harmonis dengan tindakan yang diambil baik dalam pemahaman ontologis dan tindakan dalam arti sebenarnya.

Paul Ricoeur menyebutkan bahwa tindakan selalu memiliki serangkaian makna yang dapat dimengerti oleh pelaku tindakan tersebut maupun oleh orang lain yang terkait dengan kejadian tindakan. Karakter tindakan seperti ini disebutkan Ricoeur dengan karakter yang dapat dibaca sebagai padanan dari tindakan yang bermakna (Max Webber). ${ }^{14}$ Artinya, suatu tindakan menjadi dapat dibaca dan dipahami oleh yang lainnya karena tindakan tersebut selalu meninggalkan jejak dan menjadi inskripsi sosial. Ini karena tindakan terjadi dalam konteks waktu dan selalu mengikut sertakan pelakunya (subjek dan objek tindakan) serta mempunyai tujuan tertentu ${ }^{15}$.

Dalam kerangka perasaan senasib dan sepenanggungan di dalam perjuangan bangsa, bahkan haruslah lebih didominankan bagaimana visi dan misi yang diwujudkan secara sadar bersama-sama sebagai satu kelompok komunitas bangsa, dapat dibangun dengan mencerminkan kepribadian dan identitas nasional, yakni kepribadian Pancasila. Di sini personifikasi bangsa dapat didefinisikan sebagai "kualitas perilaku kolektif kebangsaan yang unik, baik yang tercermin dalam kesadaran, pemahaman, rasa, karsa, dan perilaku berbangsa dan bernegara dari hasil olah pikir, olah hati, olah rasa dan karsa, serta olah raga seseorang dalam kelompok kehidupan berbangsa.

Politik Hukum merupakan aktivitas untuk menentukan suatu pilihan mengenai tujuan dan cara-cara yang hendak dipakai untuk mencapai tujuan hukum dalam masyarakat dengan cara meneliti perubahan-perubahan mana yang perlu diadakan terhadap hukum yang ada agar memenuhi kebutuhan-kebutuhan baru di dalam kehidupan masyarakat. Dalam proses dan pembentukan peraturan perundang-undangan

12 Ide dasar yang disampaikan oleh Gadamer adalah bahwa pendekatan kita terhadap sebuah fenomena historis (karya seni, karya sastra, teks, dan lain-lain) telah ditentukan lebih dulu oleh pemahaman awal (preunderstandings) dari interpreter-interpreter sebelumnya. Jadi, dengan melepaskan ikatan-ikatan kita sendiri terhadap objek, dan menggantinya dengan hasil interpretasi dari para interpreter sebelumnya, maka kita telah berada pada suatu jaringan interpretasi (interpretational lineage). Dan melalui kesadaran akan efek historis ini, dua titik yang semula terpisah, yaitu subjek dan objek, menjadi tersatukan menyeluruh. Proses ini oleh Gadamer dinamakan fusi horizon (fusion of horizons). Ibid.

13 A. Khozin Afandi, Langkah Praktis merancang Proposal,(Surabaya: Pustakamas, 2011), hlm. 216-220.

14 Bagi Weber tindakan yang bermakna merupakan tindakan sesorang yang mempunyai pengaruh bagi individu lain dalam interaksi sosial. Menurut Weber, tindakan adalah memahami pikiran dan perasaan-perasaan para pelaku sosial. Untuk itu, kemudian Weber membedakan tindakan sosial dengan tingkah laku pada umumnya lihat Max Weber. Economy and Society (Los angeles: Universty of California Press, 1956), hlm. 1375-1380.

15 Paul Ricoeur, From Teks to Action edited by John B. Thomson (Cambridge: Cambridge University Press, 1982), 77-78. Lihat juga, Suhermanto Ja'far, Islam, Ideologi dan Kesadaran Sosial: Sebuah Refleksi Teologi Kontekstual (Surabaya: eLKAF, 2002), hlm. 61-82. 
sebagian masyarakat Indonesia masih banyak menimbulkan perdebatan, diperbincangankan oleh masyarakat, komunitas paguyuban tertentu, kalangan mahasiswa dan akademisi serta pertanyaan-pertanyaan yang mendalam, dalam hal ini peraturan perundang-undangan salah satunya adalah rencana revisi undangundang tentang tindakpidana korupsi dikalangan penggiat anti korupsi menyadari bahwa revisi belum diperlukan karena undang-undang tersebut sudah efektif untuk memberantas korupsi dari sisi yuridis formal, sedangkan pihak legislatif meminta agar revisi terhadap undangundang tentang tindak pidana korupsi dilakukan untuk melakukan penguatan dan kontrol kelembagaan KPK dalam melakukan proses hukum tentang penyelidikan dan penindakan hingga penuntutan tidak melanggar hukum yang berlaku. Di kalangan akademisi, organisasi masyarakat maupun aktivis anti korupsi, rencana revisi undang undang ini banyak menimbulkan perdebatan permasalahan dan tidak dapat diterima, buktinya masyarakat banyak melakukan aksi pertentangan baik dilakukan dengan unjuk rasa maupun 'perang' dimedia sosial, arus penolakan untuk direvisi sangat terasa pada saat ini dengan menolak untuk dilakukan revisi terutama pelemahan terhadap kelembagaan Komisi Pemberantasan Korupsi tersebut. Kekecewaan dan ketidakpuasan atas produk hukum yang akan berlaku itu seringkali muncul dalam pemberitaan di media cetak maupun elektronik, bahkan sampai pada pembicaraan di kalangan masyarakat umum. Produk hukum berupa peraturan perundangan, peraturan kebijakan, keputusan atau ketetapan, sampai surat edaran, dianggap tidak dapat menyelesaikan masalah bahkan seringkali menimbulkan masalah baru sehingga revisi undang-undang tentang tindak pidana korupsi tersebut sampai sekarang masih dalam prokontra yang belum memilki kesimpulan.

Dengan adanya interaksi antara kesadaran hukum dan pembentukan hukum dalam kerangka tersebut maka kesadaran atau rasahukum yang hidup adalah sumber satu-satunya dari pada hukum belum tercermin dari hukum yang dijelmakan melalui peraturan perundangundangan yang kemudian H. Krabbe mengatakan dalam karangannya "De Modern Staat" dari semua hukum itu entah hukum undang-undang, hukum kebiasaan, hukum yang tidak tertulis, kesadaran hukum itulah yang merupakan basis dari pada hukum ${ }^{16}$. Didalam relasi politik hukum dan kesadaran hukum masyarakat yang demikian didalam proses pembentukan hukum seperti hal diatas terdapat kesadaran hukum masyarakat yang acapkali menjadi pertimbangan politis bagi sebagian pihak yang tidak dapat diabaikan didalam proses legislasi. Jika memang terjadi fenomena pertentangan dalam memahami kesadaran hukum masyarakat dalam konteks hal di atas, apakah harus membuat suatu peraturan perundang-undangan yang malah menimbulkan pergolakan lain yang merasa peraturan tersebut tidak adil dan menumpulkan senjata pemberantasan korupsi, misalnya seperti isu penyadapan harus melalui izin hakim, pemisahan penuntutan, dan adanya surat penghentian penyidikan didalam kasus tindak pidana korupsi. Keadaan yang dilukiskan di atas yaitu bahwa orang disatu pihak, acuh tak acuh atau hilang kepercayaan terhadap hukum, tetapi dilain pihak memiliki kesadaran yang naif

16 John Z Loudoe, Menemukan Hukum Melalui Tafsir dan Fakta, (Jakarta : Bina Aksara, 1985), hlm. 161. 
terhadap kekuatan yang seakan-akan menjadi Religious-magis dari pada hukum mencirikan cara berpikir kita umumnya tentang nilai-nilai yang hidup di dalam kehidupan politik, ekonomi, sosial masyarakat.

Jika memang terjadi fenomena pertentangan dalam memahami kesadaran hukum masyarakat dalam konteks keadaan di atas, apakah harus membuat suatu peraturan perundangundangan yang malah menimbulkan pergolakan lain yang merasa peraturan tersebut tidak adil dan menumpulkan senjata pemberantasan korupsi, misalnya seperti issu penyadapan harus melalui izin hakim, pemisahan penuntutan, dan adanya surat penghentian penyidikan di dalam kasus tindak pidana korupsi dalam arti yang sebenarnya.

Ditinjau dari sisi substansi hukum, kita tidak dapat memastikan bahwa materi daripada kesadaran hukum bukanlah suatu hukum karena belum pernah didapat suatu bukti bahwa isi dari kesadaran hukum adalah memang benar adanya. Kita tidak berhak untuk menyatakan misalnya bahwa kesadaran hukum sesuatu lingkungan hidup misalnya benar-benar ada atau kesadaran hukum dari seluruh anggota masyarakat ataupun dari sebagian terbesarnya menuntut suatu hal. Kita buta mengenai hal tersebut. Jadi kesadaran hukum itu adalah tidak lain daripada bayangan atau anggapan yang samar mengenai apa itu 'seharusnya' menurut hukum atau sekedar opini publik. Untuk mewujudkan buktinya maka kita harus menguasai segala keadaan dan harus dipertimbangkan sebelumnya semua factor yang mengarah pada jurusan itu. Hal tersebut dapat ditempuh dengan melakukan penelitian yang mendalam.
Kesadaran hukum sebenarnya mengandung dua sisi, sisi yang satu adalah suatu kategori dari keadaan batin individual dan sisi yang lain merupakan penentuan bersama dari suatu lingkungan tertentu, jika ada pihak diperlakukan tidak adil kemudian mengadakan reaksi maka dengan reaksi tersebut bahwa kesadaran hukumnya telah berontak sedangkan dari sisi yang lain, jika kesadaran hukum menuntut perbaikan atau ketertiban sosial dan nilaietika di masyarakat. Perbedaannya dengan peraturan-etis adalah bahwa kesadaran hukum yang individual bukan saja mencela sesuatu perbuatan atau keadaan, tetapi mengharapkan agar masyarakat pun akan bertindak terhadap perbuatan atau keadaan demikian ${ }^{17}$.

Asumsi bahwa kesadaran hukum warga masyarakat terhadap hukum yang ius constitutum mengakibatkan para warga masyarakat mematuhi ketentuan peraturan perundang-undangan yang berlaku. Sebaliknya, apabila keadaran hukum warga masyarakat terhadap hukum rendah, derajat kepatuhannya juga rendah. Hukum berasal dari masyarakat dan hidup serta berproses di dalam masyarakat, maka kesadaran didalam pembaharuan hukum tidak mungkin dilepaskan secara mutlak dari masyarakat. Ini berarti bahwa yang dihadapi adalah kenyataan-kenyataan sosial dalam arti yang luas. Kenyataan yang ada seperti yang dihadapi indonesia yaitu masyarakatnya yang heterogen dengan tingkat bentuk masyarakat yang berbeda-beda, mulai dari yang sederhana sampai pada masyarakat yang komplek, maka akan dihadapkan pada pola diferensiasi yang berbeda-beda pula yang akhirnya membawa akibat pada struktur masing-masing masyarakat.Pada masayarakat yang sederhana,

17 Ibid. Hal.162. 
hukum timbul dan tumbuh bersama-sama dengan pengalaman-pengalaman hidup warga masyarakatnya. Disini penguasa lebih banyak mengesahkan atau menetapkan hukum yang sebenarnya hidup dimasyarakat. Akan tetapi hal yang sebaliknya agaknya terjadi pada masyarakat yang kompleks. Kebhinekaan masyarakat yang kompleks menyebabkan sulit untuk memungkinkan timbulnya hukum dari bawah. Diferensiasi yang tinggi dalam strukturnya membawa konsekuensi pada aneka macam kategori dan kepentingan dalam masyarakat dengan kepentingan-kepentingan yang tidak jarang saling bertentangan. Walaupun hukum datang dan ditentukan dari atas, sumbernya tetap dari masyarakat.

Rumusan umum mengenai reaksi daripada kesadaran hukum dalam hal yang konkrit kemudian dijadikan ketentuan umum daripada kesadaran hukum adalah hal yang sulit karena kesadaran hukum baru bereaksi jika manusia sadar akan tanggung jawabnya dalam membuat putusan mengenai sesuatu hal. BTer Haar Bzn dalam karangannya de echtspraak van de landraden naar ongeschreven recht ${ }^{18}$ menulis bahwa kepala adat tidak mampu memberikan keterangan mengenai isi daripada sesuatu lembaga adat selama belum menghadapi suatu peristiwa yang konkrit dimana mereka harus memberikan suatu putusan. disini terlihat bahwa menggali hukum bukannya kesadaran hukum dari pada rakyat yang menentukan akan tetapi akan terlihat tangungjawab dari mereka yang memutuskan hal tersebut. Didalam tatanan hukum yang beroperasi dalam suatu masyarakat pada dasarnya merupakan pengejawantahan cita hukum yang dianut dalam masyarakat yang bersangkutan ke dalam perangkat berbagai aturan hukum positif, lembaga hukum dan proses (perilaku birokrasi pemerintahan dan warga masyarakat mengandung arti bahwa pada hakikatnya hukum sebagai aturan tingkah laku masyarakat berakar pada gagasan, rasa, karsa, cipta dan pikiran dari masyarakat itu sendiri).

Perubahan sosial dari suatu konfigurasi politik, sama halnya dengan perubahan yang bisa menyebabkan perubahan kesadaran hukum. Suatu golongan yang dominan dan dekat dengan penguasa politik, itulah yang memperoleh kekuasaan untuk menerapkan hukum tertentu dan membuat kebijakan-kebijakan lainya. Secara a contrario masyarakat tidak patuh pada hukum karena masyarakat tersebut dihadapkan pada dua tuntutan kesetiaan dimana antara kesetiaan yang satu bertentangan dengan kesetiaan lainnya. Misalnya masyarakat tersebut dihadapkan pada kesetiaan terhadap hukum atau kesetiaan terhadap "kepentingan pribadinya" yang bertentangan dengan hukum, seperti banyaknya pelanggaran lalu lintas, korupsi, dan anarkisme. Apalagi masyarakat menjadi berani tidak patuh pada hukum demi kepentingan pribadi karena hukum tidak mempunyai kewibawaan lagi, dimana penegak hukum karena kepentingan pribadinya pula tidak lagi menjadi penegak hukum yang baik. Adanya kekerasan horizontal dan vertikal pada dasarnya disebabkan melemahnya penerapan nilai-nilai budaya dan kesadaran hukum masyarakat yang mengakibatkan rendahnya kepatuhan masyarakat terhadap hukum dan timbulnya berbagai tindakan penyalahgunaan kekuasaan dan penyalahgunaan wewenang. Demikian juga kurangnya sosialisasi peraturan

18 Sebagaimana dikutip Achmad Ali, Menguak Tabir Hukum: Suatu Kajian Filosofis dan Sosiologis (Jakarta: Gunung Agung Tbk., 2002), hlm. 12. 
perundang-undangan baik sebelum maupun sesudah ditetapkan baik kepada masyarakat umum maupun kepada penyelenggara negara untuk menciptakan persamaan persepsi, seringkali menimbulkan kesalahpahaman antara masyarakat dengan penyelenggara negara termasuk aparat penegak hukum. Upaya yang akan dilakukan adalah dengan meningkatkan pemahaman dan penyadaran hukum di semua lapisan masyarakat terhadap pentingnya hakhak dan kewajiban masing-masing individu yang pada akhirnya diharapkan akan membentuk budaya hukum yang baik. Sebagai salah satu contoh pembentukan peraturan daerah yang bernuansa religius dengan tujuan ketertiban atau meningkatkan rasa kesadaran dalam beragama tentunya sumber ide yang dijelmakan dalam sebuah peraturan daerah memiliki ide yang kontra produktif dengan interaksi sosial yang berbeda pemahaman dan hal ini menjadi sebuah pertanggungjawaban politik masyarakat tersebut sebagai lokomotif ide terhadap produk hukum yang telah dilahirkan tersebut.

\section{Pancasila Sebagai Landasan Ideal untuk Mengakomodir Kesadaran Hukum Masyarakat dalam Politik Hukum Legislasi}

Perlunya pengakuan terhadap prinsip universalitas merupakan sebuah kondisi mutlak bagi terciptanya sebuah kesepakatan dalam diskursus yang bukan semata-mata kompromi. Prinsip universalitas menjadi basis bagi terciptanya kesepahaman dalam diskursus. Yang dimaksud prinsip universalitas adalah bahwa setiap norma-norma memiliki peluang untuk dapat memperoleh pengakuan umum dalam domain diskursus ${ }^{19}$. Prinsip universalitas menekankan bahwa nilai-nilai dan norma memiliki karakter yang universal didalam masyarakat yang majemuk dan plural.

Adanya kepentingan dari perwujudan sebuah ide yang berdasarkan tujuan tertentu untuk diakui dan dihormati hak-haknya sebagai manusia secara individu pribadi ataupun kolektif, masyarakat yang memiliki kepentingan hukum yang bersangkutan, akan mengarah kepada perlindungan hukum terhadap keberadaan dan pelaksanaan proses legislasi dengan tetap mencegah adanya disintegrasi. Ketika Keadaan belum mengakui, mengakomodir dan memberikan perlindungan hukum terhadap masyarakat yang mayoritas ataupun masyarakat yang termarginalisasikan justru merupakan potensi konflik bahkan ancaman terjadinya disintegrasi bangsa. Dalam melindungi kepentingannya masing-masing, maka manusia di dalam masyarakat harus mengingat, memperhitungkan, menjaga dan menghormati kepentingan manusia lain, jangan sampai terjadi pertentangan atau konflik yang merugikan orang lain. Tidak boleh kiranya dalam melindungi kepentingannya sendiri, atau dalam melaksanakan haknya, berbuat semaunya, sehingga merugikan kepentingan manusia lain (eigenrichting). Bagi masyarakat yang sedang berkembang, termasuk masyarakat Indonesia, bahwa masalah kesadaran hukum kian bertambah rumitnya, oleh karena faktor yaitu bahwa masyarakatnya sedang mengalami masa transisi di mana sistem norma-norma yang lama ingin ditinggalkan sedangkan pembentukan norma hukum baru melalui fase

19 Thomas McCarthy, Teori Kritis Jurgen Habermas, Terjemahan dari The Critical Theory of Jurgen Habermas, Alih bahasa oleh Nurhadi, (Yogyakarta: Kreasi Wacana, 2006), hlm, 403. 
program legislasi di tingkat lembaga negara acapkali berbenturan baik itu secara politik, kepentingan, dan tarik ulur pembahasan.

Masalah nilai dan asas sebagai landasan bagi pembentukan suatu peraturan perlu mendapat perhatian yang utama, karena asas mengandung nilai moral dan etis masyarakat memegang peranan penting, bahkan sampai pada prosesnya untuk mencapai tujuan hukum yang hakiki, yaitu memberikan kebahagiaan terbesar bagi sebanyak mungkin orang ${ }^{20} \mathrm{Di}$ samping itu hal yang mesti diperhatikan agar meminimalisir benturan tersebut, dalam politik hukum legislasi sudah seharusnya pembentukan peraturan perundang-undangan perlu dipegang teguh tiga prinsip, yaitu ${ }^{21}$ :

a. kesetiaan kepada cita-cita sumpah pemuda, proklamasi kemerdekaan, nilai-nilai filosofis yang terkandung dalam Pancasila, serta nilainilai konstitusional sebagaimana termaktub dalam UUD NRI Tahun 1945;

b. terselenggaranya negara hukum Indonesia yang demokratis, adil, sejahtera, dan damai; dan

c. dikembangkannya norma-norma hukum dan pranata hukum baru dalam rangka mendukung dan melandasi masyarakat secara berkelanjutan, tertib, lancar, dan damai serta mengayomi seluruh tumpah darah dan segenap bangsa Indonesia.

Kemunculan Pancasila sebagai dasar kesetiaan warga negara terhadap bangsa dan negara di Indonesia ialah merupakan suatu cikal bakal keanekaragaman yang secara otomatis keanekarangan itu akan selalu muncul dan akan menimbulkan nilai-nilai sosial kultural yang berbeda-beda di setiap daerah dan hal ini harus dihargai oleh negara bahkan hal ini haruslah dilindungi bukan malah sebaliknya. Hal inilah yang harus diperhatikan ketika mengakomodir kemajemukan dan pluralisme di negeri ini untuk selalu memikirkan sosial kultural yang ada di Indonesia karena hal ini sudah ada sebelum Indonesia merdeka dan hal ini tidak dapat dihilangkan begitu saja.

Secara filosofi hakikat kedudukan Pancasila sebagai paradigma sumber pembangunan hukum mengandung suatu konsekuensi bahwa dalam segala aspek pembentukan dan pembangunan hukum nasional kita harus mendasarkan pada haki-kat nilai-nilai silasila Pancasila. Oleh karena hakikat nilai silasila Pancasila mendasarkan diri pada dasar ontologis manusia sebagai subjek pendukung pokok sila-sila Pancasila sekaligus sebagai pendukung pokok negara. Hal ini berdasarkan pada kenyataan objektif bahwa Pancasila dasar negara dan negara adalah organisasi (persekutuan hidup) manusia.

Pancasila dan Undang-Undang Dasar Negara Republik Indonesia (UUD NRI) Tahun 1945 mengandung butir-butir pasal yang tidak hanya merupakan pintu gerbang masuknya norma-norma hukum yang secara kuantitatif maupun kualitatif sangat memenuhi kebutuhan masyarakat Indonesia, karena sifatnya sangat membuka diri bagi masuknya nilai-nilai agama dalam sistem hukum maupun hukum positifnasional kita, sekaligus juga akan menjadi motor pendorong, lahirnya sebuahsistem 
hukum positif nasional pada masa-masa mendatang 22 .

Karena itu setiap penyusunan peraturan perundang-undangan harus memperhatikan cita-cita moral dan cita-cita hukum sebagaimana diamanatkan didalam konstitusi. Adapun nilainilai yang bersumber pada pandangan filosofi konstitusi, yakni ${ }^{23}$ :

a. Nilai-nilai religius bangsa Indonesia yang terangkum dalam sila Ketuhanan Yang Maha Esa.

b. Nilai-nilai hak-hak asasi manusia dan penghormatan terhadap harkat dan martabat kemanusiaan sebagaimana terdapat dalam sila Kemanusiaan yang adil dan beradab.

c. Nilai-nilai kepentingan bangsa secara utuh, dan kesatuan hukum nasional seperti yang terdapat dalam sila Persatuan Indonesia.

d. Nilai-nilai demokrasi dan kedaulatan rakyat. Sebagaimana terdapat di dalam sila Kerakyatan yang dipimpin oleh hikmah kebijaksanaan dalam permusyawaratan/ perwakilan.

e. Nilai-nilai keadilan, baik individu maupun sosial seperti yang tercantum dalam sila keadilan sosial bagi seluruh rakyat Indonesia.

Pancasila yang oleh para Bapak Pendiri Negara Republik Indonesia ditetapkan sebagai landasan kefilsafatan dalam menata kerangka dan struktur dasar organisasi negara sebagaimana dirumuskan dalam UUD Negara Republik Indonesia Tahun 1945. Pancasila adalah pandangan hidup bangsa Indonesia yang mengungkapkan pandangan bangsa Indonesia tentang hubungan antara manusia dan Tuhan, manusia dan sesama manusia, serta manusia dan alam semesta yang berintikan keyakinan tentang tempat manusia individual di dalam masyarakat dan alam semesta (Pembangunan hukum dimulai dari pondasinya dan jiwa paradigma bangsa Indonesia, Pancasila sebagai sumber dari segala sumber hukum (Staatsfundamentalnorm), yang dipertegas dalam Undang-Undang 12 Tahun 2011 tentang Pembentukan Peraturan Perundang-undangan terutama Pasal 2 yang menyatakan Pancasila merupakan sumber dari segala sumber hukum atau sumber tertib hukum bagi kehidupan hukum di Indonesia, maka hal tersebut dapat diartikan bahwa "Penempatan Pancasila sebagai sumber dari segala sumber hukum negara adalah sesuai dengan Pembukaan Undangundang Dasar Negara Republik Indonesia tahun 1945 yang menempatkan Pancasila sebagai dasar dan ideologi negara serta sekaligus dasar filosofis bangsa dan negara sehingga setiap proses pembentukan, materi peraturan perundang-undangan tidak boleh bertentangan dengan nilai-nilai Pancasila". Kedudukan Pancasila sebagai sumber dari segala sumber hukum negara merupakan grundnorm dalam sistem hukum Indonesia yang memberikan arah dan jiwa serta menjadi paradigma normanorma dalam pasal-pasal UUD 1945. Cita hukum dan falsafah hidup serta moralitas bangsa yang menjadi sumber segala sumber hukum negara akan menjadi satu fungsi krisis dalam menilai kebijakan hukum (legal Policy) atau dapat dipergunakan sebagai paradigma yang menjadi landasan pembuatan kebijakan (policy making)

\footnotetext{
22 Hartono Mardjono, Menegakkan Syariat Islam Dalam Konteks Keindonesiaan: Proses Penerapan Nilai-Nilai Islam, Dalam Aspek Hukum, Dan Lembaga Negara, (Bandung: Mizan, 1997), hlm. 28.

23 Mohammad Yamin, Proklamasi dan Konstitusi Republik Indonesia, (Jakarta:Djambatan, 1952), hlm.75.
} 
dibidang hukum dan perundang-undangan maupun bidang sosial, ekonomi, dan politik.

Serta harus sejalan beriringan dengan tatanan nilai-nilai kehidupan di dalam berbangsa dan bernegara, ada yang disebut sebagai nilai dasar, nilai instrumental dan nilai praksis. Nilai dasar adalah asas-asas yang kita terima sebagai dalil yang kurang lebih mutlak. Nilai dasar, berasal dari nilai-nilai kultural atau budaya yang berasal dari bangsa Indonesia itu sendiri, yaitu yang berakar dari kebudayaan, sesuai dengan Pancasila dan UUD 1945 yang mencerminkan hakikat nilai kultural. Nilai instrumental adalah pelaksanaan umum nilai-nilai dasar, biasanya dalam wujud norma sosial atau norma hukum, yang selanjutnya akan terkristalisasi dalam lembaga yang sesuai dengan kebutuhan tempat dan waktu. Nilai instrumental, meskipun lebih rendah daripada nilai dasar, tetapi tidak kalah penting karena nilai ini mewujudkan nilai umum menjadi konkret serta sesuai dengan zaman. Nilai instrumental merupakan tafsir positif terhadap nilai dasar yang umum. Nilai praksis adalah nilai yang sesungguhnya kita laksanakan dalam kenyataan. Semangatnya nilai praksis ini seyogyanya sama dengan nilai dasar dan nilai instrumental.

\section{Penutup}

Proses legislasi merupakan aktualisasi politik hukum yang berdasarkan kesadaran hukum masyarakat untuk mencapai tujuan dan melindungi kebutuhan dan kepentingan masyarakat. Upaya untuk memelihara tertib hukum, dan ketaatan terhadap hukum yang telah dibentuk tidak hanya dipengaruhi oleh faktor juridis semata, tetapi juga dipengaruhi oleh faktor non juridis seperti kesadaran hukum, budaya hukum masyarakat sebagai pemegang peranan dalam aplikasi dan implikasinya.
Indonesia sebagai negara bangsa yang majemuk memerlukan suatu sistem hukum modern yaitu seperangkat atau suatu sistem hukum yang mampu mengantisipasi serta mengatasi berbagai permasalahan yang mungkin akan timbul. Salah satu dimensi mutlak dalam pembentukan sistem hukum Indonesia yang modern adalah senantiasa mencerminkan dan mengedepankan rasa keadilan dan kesadaran masyarakat Indonesia dan sesuai cita hukum dan cita-cita moral dalam nilai-nilai Pancasila dan UUD NRI tahun 1945. Nilai-nilai Pancasila dijadikan sarana untuk mengakomodir dimensi kepentingan politik, ekonomi, sosial dan politik manusia sebagai subjek didalam bernegara.

\section{DAFTAR PUSTAKA}

\section{Buku}

Adian, Donny Gahral, Percik Pemikiran Kontemporer, (Yogyakarta: Jalasutra, 2006)

Afandi, A. Khozin, Langkah Praktis merancang Proposal, (Surabaya : Pustakamas, 2011)

Ali, Achmad. Menguak Tabir Hukum: Suatu Kajian Filosofis dan Sosiologis, (Jakarta: Gunung Agung Tbk., 2002)

Angeles, Peter A., A Dictionary of Philisophy, (London: Harper \& Row Publishers, 1981),

Hadiwijono, Harun, Sari Sejarah Filsafat Barat 2, (Yogyakarta: Kanisius, 2002)

Hardiman, F. Budi, Heidegger dan Mistik Keseharian; Suatu Pengantar Menuju Sein und Zeit, (Jakarta: KPG Kepustakan Populer Gramedia, 2003)

Hartono, Sunarjati, Capita Selecta Perbandingan Hukum, (Bandung, Alumni, 1968)

Ja'far, Suhermanto, Islam, Ideologi dan Kesadaran Sosial: Sebuah refleksi Teologi Kontekstual, (Surabaya: eLKAF, 2002)

Loudoe, John Z, Menemukan Hukum Melalui Tafsir dan Fakta, (Jakarta: Bina Aksara, 1985)

M.D, Mahfud,. Politik Hukum di Indonesia, (Jakarta: PT. Raja Grafindo Persada), 2012

Mardjono, Hartono, Menegakkan Syariat Islam dalam Konteks Keindonesiaan, Proses Penerapan Nilai-Nilai Islam, dalam Aspek Hukum, dan Lembaga Negara, (Bandung: Mizan, 1997) 
McCarthy, Thomas, Teori Kritis Jurgen Habermas, Terjemahan dari The Critical Theory of Jurgen Habermas, Alih bahasa oleh Nurhadi, (Yogyakarta: Kreasi Wacana, 2006)

Poespoprodjo, W., Interpretasi: Beberapa Catatan Pendekatan Filosofisnya, (Bandung: Remadja Karya, 1987)

Rahardjo, Satjipto, Hukum Dan Masyarakat, (Bandung, Angkasa, 1980)

Ritzer, George dan Barry Smart, Hand Book Teori Sosial, (Jakarta: Nusamedia, 2012)

Saifritlah, Reflekssi Sosiologi Hukum, (Bandung: PT.Refika Aditama, 2007)

Soekanto, Soerjono dan Sri Mamudji, Penelitian Hukum Normatif Suatu Tinjauan Singkat, Cetakan ke - 11. (Jakarta : PT Raja Grafindo Persada, 2009)

Warassih, Ismi, Mencari Model Ideal Penyusunan UU Yang Demokrasi, (Semarang: FH UNDI, 1999)

Yamin, Mohammad, Proklamasi dan Konstitusi Republik Indonesia, (Jakarta: Djambatan, 1952)

\section{Makalah/Artikel/Prosiding/Hasil Penelitian}

Rukka, Singkeru, "Kearifan Lokal Dan Kesadaran Hukum", Jurnal Al-Risalah, Volume 13 Nomor 1 Mei (2013)

\section{Internet}

Siahaan, Pataniari, Membangun Kerangka Politik Perundang-undangan yang jelas dan terarah melalui prolegnas, dikases dari http://www. parlemen.net/ sites/ default/ files/ dokumen/ Membangun\% 20Kerangka\% 20Politik\% 20Perundang-undangan\%2026Mei08.pdf (diakses 26 Mei 2008)

\section{Peraturan}

Undang-Undang Dasar Negara Republik Indonesia 1945

Undang-Undang Nomor 12 Tahun 2011 tentang Pembentukan Peraturan Perundang-Undangan 